\title{
既知解を重畳した表面電荷法による高速電界解析
}

$\begin{array}{llllll}\text { 正員 坪 } & \text { 井 } & & \text { 始 } & \text { (福山大) } \\ \text { 正員 } \text { 由 } & \text { 中 } & \text { 始 } & \text { 男 } & \text { (福山大) } \\ \text { 正 員美 } & \text { 咲 } & \text { 隆 } & \text { 吉 } & \text { (福山大) } \\ \text { 正員 八 } & \text { 束 } & & \text { 健 } & \text { (住友電工) } \\ \text { 正員 岸 } & & \text { 幸 } & \text { 治 } & \text { (住友電工) }\end{array}$

\section{Efficient Electric Field Analysis by the Surface Charge Simulation Method Superposing Known Field Distribution}

Hajime Tsuboi, Member, Motoo Tanaka, Member, Takayoshi Misaki, Member (Fukuyama University), Ken Yatsuka, Member, Koji Kishi, Member (Sumitomo Electric Industries)

\begin{abstract}
Numerical analysis of electric field is performed by several practical methods. The surface charge simulation method is used for three-dimensional analysis of static electric field in the medium with constant and homogeneous permittivity. The number of unknowns becomes large in practical problems, and large memory storage and long computation time are required. Therefore, when a computation model where the electric field distribution is known is given and a small conductor is added to the computation model, we propose an efficient method superposing the known electric field distribution. In the proposed method, the surface charges induced by the added small conductor are used as unknowns. By using the proposed method, the area to be analyzed becomes small and the number of unknowns is reduced. The formula for the proposed method and how the area to be analyzed is determined are shown. Furthermore, some numerical examples and an application for the power cable with defect are presented.
\end{abstract}

キーワード：表面電荷法, 電界解析, 高電圧機器, 数値解析

\section{1、まえがき}

電界の数值解析は，種々の実用的な手法によって行 われている(1) (3) が, 誘電率が一定で一様な場合の三 次元静電界解析に㳊表面電荷法がしばしば用いら れ(4)(5)，電極形状や絶縁物形状の最適化にも用いられ ている(6‘7)。また, 表面電荷法には, 計算精度の向上 のための曲面要素の導入(4), 数值積分法の改良(5)(8)(9) などの改良がなされている。しかし，実用問題の三次 元電界解析では, 未知数 (未知表面電荷密度数) が多 くなり，膨大な記憶容量と計算時間を必要とすること がある。この場合，最終の連立一次方程式の係数行列 は密行列となるため，係数行列を格納する記憶容量と これを作成する計算時間は未知数の二重に比例し，連
立方程式をガウスの消去法で解く計算時間は未知数の 三乗に比例する。

そこで，表面電荷法などの積分方程式法では重畳の 理によって睡知解を含む解析が容易にできる゙こと に着目し，解析解や数值解などの既知解がある形状に 微小導体が付加された計算モデルの場合にここれらの 既知解を用いることによって未知数を隇らし，計算を 高速化する手法を提案する。このとき，重疊の理を用 いて既知の電荷分布に未知の電荷分布を重畳して解析 を行い，末知数を減少させる。まず定式化を示し，次 に適用法を検討し，軸対称問題と三次元問題の計算例 を示す。更に，実用例として，提案手法を電力ケーブ ル内に微小異物が混入した場合の三次元電界解析に応 用した例を示す。 


\section{2. 計算の原理と基本式}

表面電荷法では，導体表面と誘電体境界面に定義さ れた，見掛け電荷の電荷密度を未知変数として電界解 析を行う。ここでは, 図 1 (a)に示す簡単な二導体モ デルを考える。(b)図のように導体 $A$ に電位 $V_{A}$ が 印加された場合の解がある場合を考える。この場合に は, 導体 $A$ 上の表面電荷密度は既知の值 $\sigma_{0}$ である。 次に，導体 $A$ と導体 $B$ が存在する場合を考えると， 導体 $A$ 表面上の表面電荷密度 $\sigma_{A}$ は, 重畳の理によ $\eta \sigma_{0}$ と導体 $B$ による誘導電荷 $\sigma_{a}$ の和となる。遵体 $B$ が導体 $A$ に比べて相対的に微小であると，その影 響は導体 $B$ から離れたところにはほとんど及ばず， (c)図に示すように $\sigma_{a}$ は近似的に導体 $A$ の表面 $S_{A}$ の一部の $S_{a}$ にのみ誘導されることになる。 $S_{a}$ は, $S_{A}$ から $\sigma_{a}$ が零と見なせる部分を差し引いた範囲であ る。このとき， $\sigma_{0}$ は既知であるので， $\sigma_{a}$ と導体 $B$ 表 面 $S_{B}$ 上の表面電荷密度 $\sigma_{B}$ を末知として $(\mathrm{a})$ 図の問 題を解くことができる。

表面電荷法では， $\varepsilon_{0}$ の媒質で满たされた空間の任 意の計算点 $i$ の電位 $V i$ は, 次式で計算される。

$$
V_{i}=\frac{1}{\varepsilon_{0}} \iint_{S} \sigma \phi d S
$$

ここで, $\varepsilon_{0}:$ 真空の誘電率, $S:$ 導体表面と 誘電体境界面を合わせた全境界面， $\phi$ : 基本 解

図1の計算モデルを考えると，(1)式のSとのは 次式で表される。
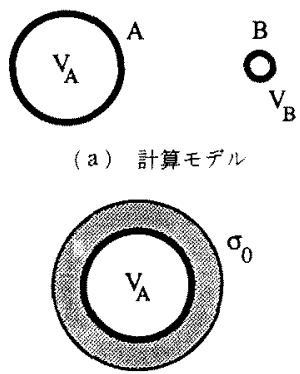

（b） 既知表面電荷密度

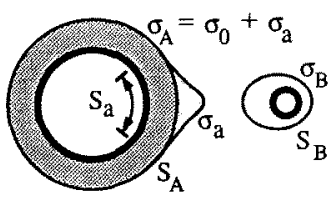

（c）既知表面婯荷密度と 未知表面電荷密度の重葍

図 1 計算の原理

Fig. 1. Principle of the calculation.

$$
\begin{aligned}
& S=S_{A}+S_{B} \ldots \\
& \sigma=\sigma_{A} \quad\left(S_{A} \text { 上 }\right) \\
& \sigma=\sigma_{B} \quad\left(S_{B} \text { 上 }\right)
\end{aligned}
$$

また

$$
\sigma_{A}=\sigma_{0}+\sigma_{a}
$$

そこで，(2)〜（4)式を用いて(1)式を書き換える と, 次のようになる。

$$
\begin{aligned}
& V_{i}=\frac{1}{\varepsilon_{0}} \iint_{S_{A}} \sigma_{0} \phi d S+\frac{1}{\varepsilon_{0}} \iint_{S_{A}} \sigma_{a} \phi d S \\
& +\frac{1}{\varepsilon_{0}} \iint_{S_{B}} \sigma_{B} \phi d S
\end{aligned}
$$

上式の右辺第 1 項は, 既知の電荷密度 $\sigma_{0}$ による電位 であるから既知電位 $V_{0 i}$ とおける。また， $\sigma_{a}$ が誘導 される表面を $S_{a}$ で近似すると，(5)式は次のように 書き換えられる。

$$
V_{i}=V_{0 i}+\frac{1}{\varepsilon_{0}} \iint_{s_{a}} \sigma_{a} \phi d S+\frac{1}{\varepsilon_{0}} \iint_{S_{B}} \sigma_{B} \phi d S
$$

同様に，任意の点 $i$ の電界 $E_{i}$ は，次式で与㫕られ る。

$$
\begin{aligned}
& E_{i}=E_{0 i}-\frac{1}{\varepsilon_{0}} \iint_{S_{a}} \sigma_{a} \nabla \phi d S-\frac{1}{\varepsilon_{0}} \iint_{S_{B}} \sigma_{B} \nabla \phi d S \\
& \text { ここで， } E_{0 i} ： \sigma_{0} \text { による既知電界 }
\end{aligned}
$$

(6)，(7)式を用いて，次のように与えられる導体 表面の電位条件と誘電体境界面の電束の連続条件と加 ら表面電荷法の最終の連立方程式が作成される。

$$
\frac{1}{\varepsilon_{0}} \iint_{S_{a}} \sigma_{a} \phi d S+\frac{1}{\varepsilon_{0}} \iint_{S_{s}} \sigma_{B} \phi d S=V_{i}-V_{0 i}
$$

(導体表面の電位条件)

$$
\begin{gathered}
\frac{\varepsilon_{2}-\varepsilon_{1}}{\varepsilon_{0}}\left(-\iint_{S_{a}} \sigma_{a} \nabla \phi d S-\iint_{S_{B}} \sigma_{B} D \phi d S\right) \\
+\frac{\varepsilon_{2}+\varepsilon_{1}}{2 \varepsilon_{0}} \sigma_{i}=-\left(\varepsilon_{2}-\varepsilon_{1}\right) E_{0 i}
\end{gathered}
$$

（誘電体境界面の電束の連続条件）

ここで， $\varepsilon_{1}, \varepsilon_{2}$ : それぞれ境界面に接する二

\section{つの誘電体の誘電率}

(8)，（9)式を用いて解く問題の計算規模は，Sa と $S_{B}$ 上の末知表面電荷を求める表面電荷法と同等に なるため, 誘導電荷が定義される $S_{a}$ が狭いほど從来 法に比べて計算が高速化されることになる。

(6)，（7)式の既知電位と既知電界は, 解析解, 数 值解など，都合の良い方法で求められる。従って，従 来の表面電荷法の解析プログラムのわずかな修正のみ で提案手法の解析プログラムが作成可能である。 


\section{3. 誘導電荷定義範囲の決定法}

誘導電荷が定義される $S_{a}$ が狭いほど計算が高速化 されるが，適切な範囲を用いないと計算精度の低下を まねくことになる。すなわち， $S_{a}$ は近似的に $\sigma_{a}$ が零 ではないとみなせる範囲を用いるため，範囲が狭すぎ ると計算精度の低下をまねき，広すぎると計算時間が 長くなり非能率的である。

実用モデルでは, 複雑な形状, 複雑な配置を扱う必 要があるが，単純化したモデルで $S_{a}$ の範囲を検討す る。図2 に示す球一平板導体モデルを用い, 球導体を 付加される微小導体，平板導体を微小導体による誘導 を受ける比較的大きな導体と仮定した。 $E=\sigma / \varepsilon_{0}$ の関 係があるから，平板上の電界 $E$ を求めて，次式で表 される導体球直下 $(x=0)$ の電界 $E_{0}$ に対する減少率 $\eta$ から $S_{a}$ の範囲を検討した。

$$
\eta=\frac{E}{E_{0}} \times 100(\%)
$$

実用計算では，最大電界の計算愦差を $1 \%$ 以内と考 え，微小導体によって誘導される電荷の全電荷に占め る割合は小さいと考えて， $\eta=1 \%$ 以となる $S_{a}$ を考 える。

また，電界強度は解析解(10) を用いて計算した。図 2(a)において， $a$ は平板から球面までの距離，bは 平板から球の中心までの距離， $U$ 性導体の電位， $r$ は球の半径である。ここで，(導体間の電位差）／（導 体間の距離) $=1$ となるように, 球導体の電位 $U$ は $a(\mathrm{~V})$, 平板の電位は $0 \mathrm{~V}$ とした。

図 3（a）に示すように球埒体が平板から離れると, $U=a$ としているので球面上の最大電界値 $E_{\max }$ は増 大して平面上の最大電界值 $E_{0}$ 減少しているが, (b)図に示すように $b / r$ が 3 以上では， $x / b$ の值がー

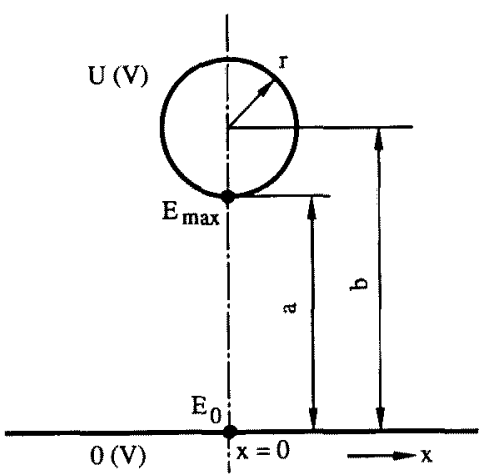

図 2 球一平板導体モデル

Fig. 2. Conducting sphere-plate model.

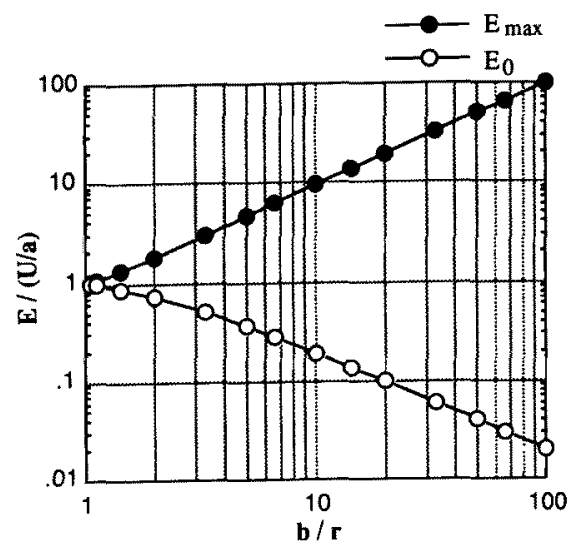

(a) 電界強度

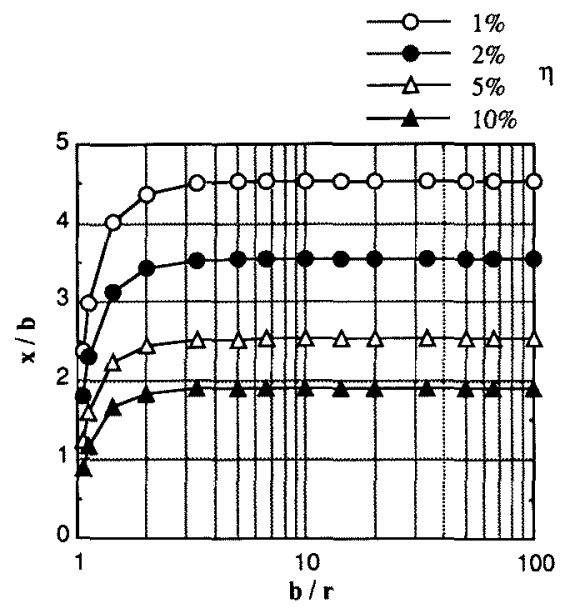

(b) 電界分布

図 3 球一平板導体モデルの電界分布の変化 Fig. 3. Changes of the electric field distributions of the conducting sphere-plate model.

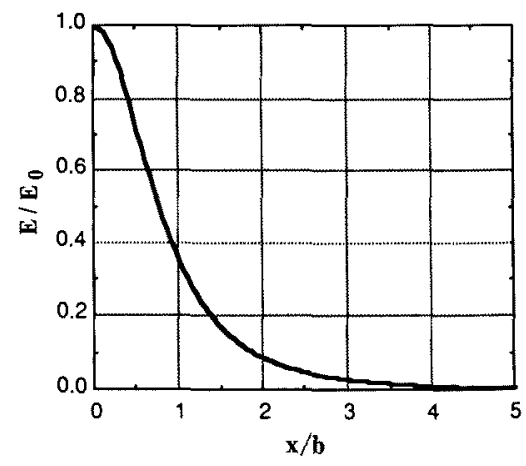

図 4 平板上の電界分布

Fig. 4. Distribution of the electric field on the plate. 
定值になっている。すなわち，球導体がその半径の約

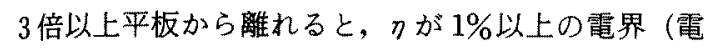
荷) が誘導される範囲は平板と球の距離 $b$ の約 4.5 倍以内の籍囲に限られることを示している。従って, 正規化した電界分布は，(b)図から b/rが 3 以上で同 形となることがわかり，図4 に示す1本のグラフで表 される。

図 $3(\mathrm{~b})$ から, 誘導電荷が定義される $S_{a}$ を円形の 領域で近似すると, その半径は, 付加される導体が微 小で平均半径の 3 倍以上距離が離れていれば, 微小導 体と誘導を受ける導体との距離の 4.5 倍以上の範囲に とればよいことがわかる。

また，以上治導体のみの計算モデルについて検討し てきたが，導体の代わりに誘電体が付加された場合に も以上述べた考方方を搪張できると考えられる。

\section{4. 計 算 例}

$\langle 4 \cdot 1\rangle$ 二球導体モテル 大きさの異なる二つの 球導体の計算モデルを図 5 に示す。 $A B$ 間は, 提案手 法における大球表面上の誘導電荷の定義範囲で, この 部分のみを要素分割する。この場合, $A B$ 間の距離 は, 図 3(b)の結果から $0.45 \mathrm{~m}$ 程度でよいと考えら れるが，小球によって誘導さ机る電界分布を確認する ために $0.8 \mathrm{~m}$ としている。また, 従来法では $A B_{0}$ 間 をすべて要素分割する必要がある。

この計算モデルは軸対称問題または三次元問題とし て解析できるが，ここでは計算モデルを従来法で解く 場合と提案手法を用いる場合の比較を軸対称解析と三 次元解析の両解析手法で検討する。 $A B$ 間または $A B_{0}$ 間は, 軸対称問題では形状を三次関数で近似す る曲線要素(6)で分割され, 三次元問題では球面とな るので，図 6 に示すように形状を五次関数で近似する 曲面三角形要素(6)で分割される。ここで，小球と

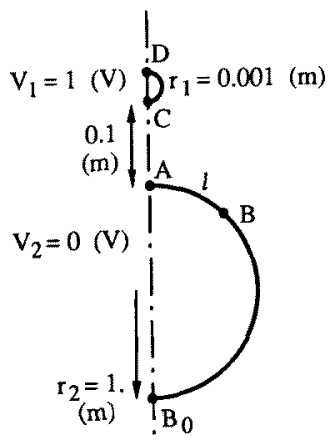

図 5 二球導体モデル

Fig. 5. Two-conducting sphere model.
$A B$ 間の要素分割は, 従来法, 提案手法とも同じであ る。表面電荷密度は, 曲線要素, 曲面三角形要素とも 座標の一次関数で近似している(6)。要素分割数, 未知 節点数などの計算条件と計算結果を表 1 に示す。既知 解として証立球の解析解を用いた。軸対称解析の計 算結果のほうが計算精度が高くなっているのは, 分割 が細かいためであるが，軸対称解析と三次元解析にお いて, どちらの場合も従来法と提案手法の計算結果は よく一致している。表 1 より，提案手法により約 20〜 $30 \%$ に計算時間が短縮されていることがわかる。図 7 に, 大球表面の電界分布の計算值を示す。lが 0.45 付近より近い電界はほ添零となり，前述したように $A B$ 間の距離は $0.45 \mathrm{~m}$ 程度でよいことがわかる。

〈4・2〉同心球導体モテル 図 $8(\mathrm{a})$ に同心球導 体間に小球が入れられた計算モデルを示す。内球と外

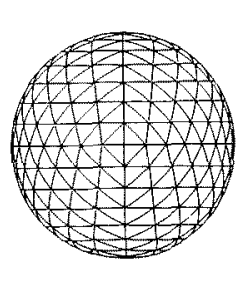

(a) 小球
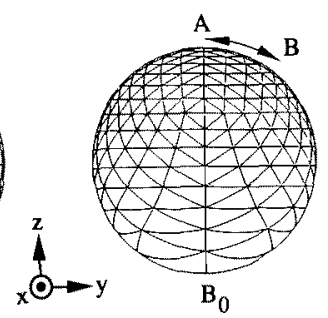

(b) 大球
図 6 二球導体モデルの三次元解析用分割図 Fig. 6. Arrangement of the curved surface triangular element for the two conducting sphere model.

表 1 二球導体モデルの計算結果

Table 1. Computation results of the two conducting sphere model.

\begin{tabular}{|c|c|c|c|c|c|}
\hline & & \multicolumn{2}{|c|}{ 軸対称解析 } & \multicolumn{2}{|c|}{ 三次元解析 } \\
\hline & & 徉来法 & 提案手法 & 従来法 & 提案手法 \\
\hline \multirow{2}{*}{ 要琹数 } & 大球 & 128 & 32 & 512 & 144 \\
\hline & 小球 & 64 & 64 & 512 & 512 \\
\hline \multicolumn{2}{|c|}{ 末知節点数 } & 194 & 98 & 516 & 340 \\
\hline \multirow{2}{*}{$\begin{array}{l}\text { 電界 }(\mathrm{V} / \mathrm{m}) \\
\text { [铞差 }(\%)]\end{array}$} & $A$ 点 & $\begin{array}{l}1.191 \\
{[0.3]}\end{array}$ & $\begin{array}{r}1.192 \\
(0.3)\end{array}$ & $\begin{array}{l}1.194 \\
{[0.5]}\end{array}$ & $\begin{array}{l}1.200 \\
(1.0)\end{array}$ \\
\hline & $C$ 点 & $\begin{array}{c}-914.7 \\
(0.0)\end{array}$ & $\begin{array}{c}-914.7 \\
(0.0)\end{array}$ & $\begin{array}{c}-910.7 \\
(0.5)\end{array}$ & $\begin{array}{c}-910.4 \\
{[0.5]}\end{array}$ \\
\hline \multirow{3}{*}{$\begin{array}{c}\text { 計算時間 } \\
\text { (s) }\end{array}$} & $\begin{array}{c}\text { 係数行列 } \\
\text { 作成 }\end{array}$ & 91 & 23 & 162 & 70 \\
\hline & $\begin{array}{c}\text { ガウスの } \\
\text { 消去法 }\end{array}$ & 28 & 4 & 276 & 78 \\
\hline & 計 & 119 & 27 & 438 & 148 \\
\hline
\end{tabular}

使用計算機：SONY NEWS 3860 (R 3000, $20 \mathrm{MHz}, 20 \mathrm{MIPS}$ ) 


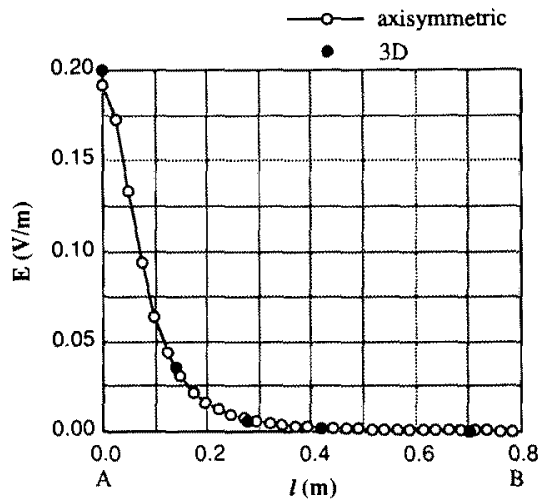

図 7 大球表面の誘導電界の分布

Fig. 7. Distribution of the induced electric field on the surface of the large sphere.

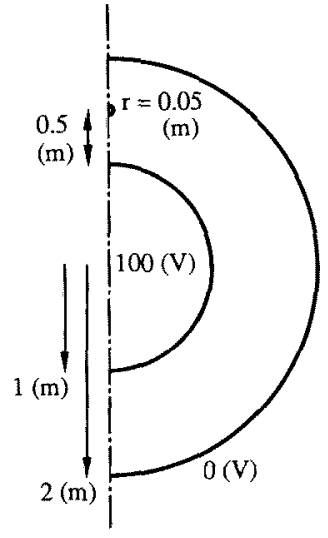

(a) 計箅きデル

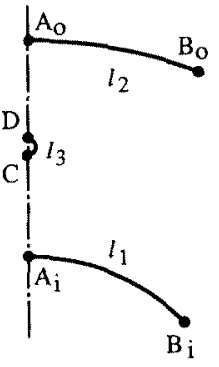

（b）未知歨面䇩荷が 定美古九る領域

\section{図 8 同心球モデル}

Fig. 8. Concentric sphere model.

球表面には，(b)図に示すように誘導電荷を定義し， 軸対称解析を行った。既知解としては同心球導体の解 析解を用いた。

小球は絶縁されているため，全電荷が零で，電位が 未知のいわゆる浮遊導体である。ここでは，小球の電 位として適当な值を仮定して解析し，求めら机た表面 電荷密度より小球の全電荷を計算してこ礼が零になる 上うに，二分法を用いて繰り返し計算を行い，最終的 な小球の電位を求めた。このことにより, 解析プログ ラムの変更なしに浮遊導体の解析が可能である。図 8 の計算モデルでは，小球の電位は $33.33 \mathrm{~V}$ となった。 導体表面の電界分布の計算結果を図 9 に示す。図 3 (b)の基準では， $A_{i} B_{i}$ 間および $A_{0} B_{0}$ 間の距離は 2.3 $\mathrm{m}$ 程度とる必要があるが, その約 $1 / 4 の l_{1}, l_{2}=0.6 \mathrm{~m}$ 程度で誘導電界は零となっている。これは, 図 3 の

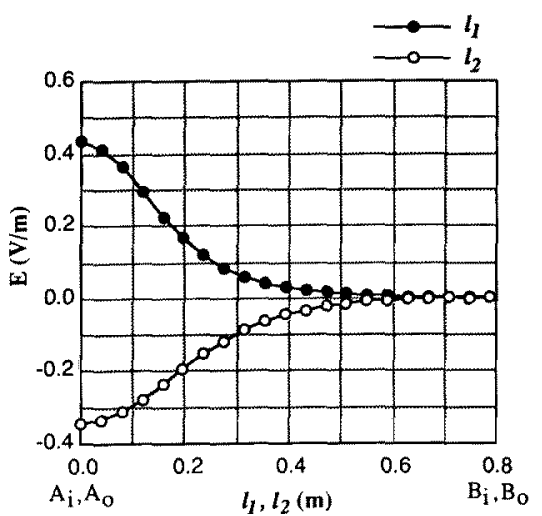

(a) 同心球表面以誘導さ扎る電界

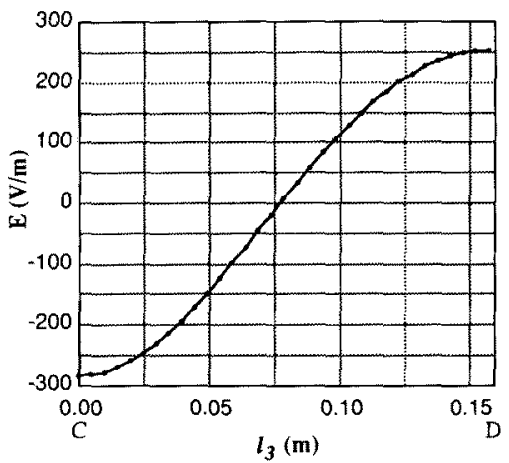

（b）小球表面の電界分布

図 9 導体表面の電界分布

Fig. 9. Distributions of the electric field on the surface of the conductor.

結果注開領域の場合であり，本モデルは閉領域の問題 であるので，相対する導体により誘導電界の生じる範 囲が狭められていると考えられる。すなわち，外部導 体のない開領域問題の場合には小球から出た電気力線 は点 $B_{i}$ 上り遠くまで達するが，外部導体のある閉領 域問題の場合には外部導体加ら直接内部導体に達する 電気力線が多数あり（外部導体による誘導電界が大き く，小球から出た電気力線は遠くまで広がらないた めである。従って, 図 $3(\mathrm{~b})$ の結果は誘導電界の生じ る最大範囲を示すと考えられ，本モデルのような閉領 域の問題では範囲は狭められる。

〈4・3〉 電カケーブルモテル＼cjkstart実用問題として電 カケーブル内に微小異物が混入した場合の計算モデル を図 10 に示す。本モデルは三次元モデルであり，䋓 縁厚 $2 \mathrm{~mm}$ のケーブルに直径 $0.2 \mathrm{~mm}(200 \mu \mathrm{m})$ の球 状の金属異物が混入した場合の電界解析例である。そ の要索の分割を図 11 に示す。球導体表面は 288 の曲 面三角形要素に分割している。前節の結果から円筒面 

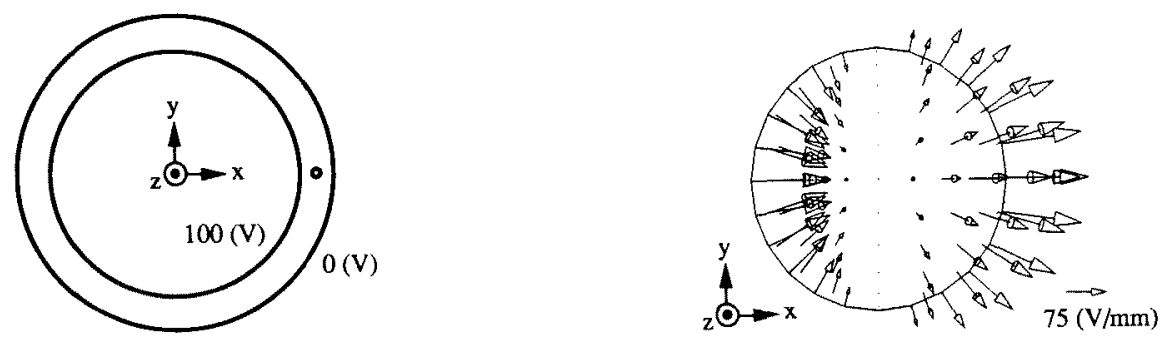

図 12 球導体表面の電界分布

Fig. 12. Distribution of the electric field on the surface of the conducting sphere.

は半径 $1 \mathrm{~mm}$ の範囲を分割すればよいが，分割の容易 さから内円筒面は $2 \mathrm{~mm} \times 2 \mathrm{~mm}$, 外円筒面は $2 \mathrm{~mm} \times$ $2.48 \mathrm{~mm}$ の円筒面上の長方形領域をそれぞれ 200 分 割している。未知節点数㹥 388 で，計算時間は $190 \mathrm{~s}$ であった。図 12 に小球表面の電界分布の計算結果を 示す。内円筒面に対向する $A$ 点と外円筒面に対向す る $B$ 点の電界は，そ机ぞれ $1.500 \times 10^{2} \mathrm{~V} / \mathrm{mm}$ と $1.511 \times 10^{2} \mathrm{~V} / \mathrm{mm}$ であった。

電力ケーブルモデルの三次元解析では，一般に端部 図 10 電力ケーブルモデル

Fig. 10. Power cable model.

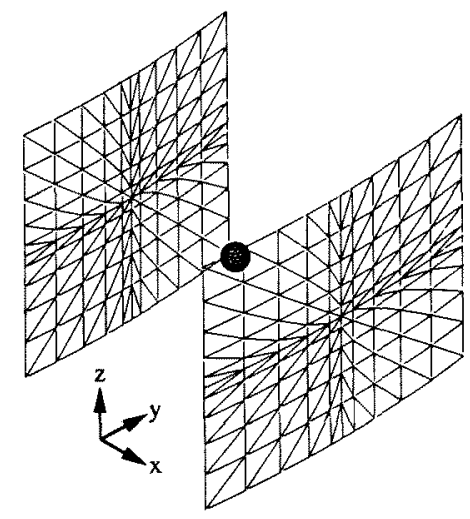

(a) 全体図

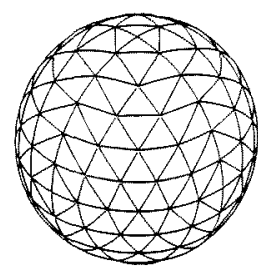

(b) 球道 体

図 11 電力ケーブルモデルの分割図

Fig. 11. Arrangement of the curved surface triangular elements for the power cable model.

の影響がなくなるように 儿を作成して解析を行う必要があり，計算規模が大き くなる傾向がある。すなおち，同様の計算を従来法で 行う場合, 外円筒の直径の約 6 倍の範囲の円筒面を要 素分割する必要があるため，内外円筒上の曲面三角形 要素数は 1,976 となり，全末知節点数は 1,186 となっ た。計算時間は約 70 分で，提案手法の約 23 倍の計算 時間を要した。このように，提案手法を用いれば，円 筒面の誘導電荷が生じる部分のみを要素分割すればよ く，計算規模を著しく縮小できることがわかった。

\section{5.むすび}

以上，表面電荷法による電界解析において，既知解 を用いた計算の高速化手法を提案し，その定式化を示 すとともに，計算結果について検討した。得られた結 果をまとめると次のようになる。

（1）解析解や数值解などの既知解のある形状に微 小導体が付加された計算モデルで法，既知解を用い て，これに重嘼される付加導体による誘導表面電荷密 度のみを末知変数とすれば末知数が隇少し, 計算が高 速化できる。この場合, 係数行列の作成時間は未知数 の二乗に比例し，ガウスの消去法の計算時間は未知数 の三乗に比例するので，付加導体による誘導電荷の生 じる範用が全体に占める割合で提案手法による高速化 の効果が決まる。

（2）付加導体によって表面電荷が誘導される範囲 
は, 付加導体の大きさと誘導を受ける導体との距離で 決まる。すなわち，付加導体形状を球で近似したとき の平均半径の 3 倍以上, 付加導体が誘導を受ける導体 から離れている場合に, 誘導される範囲を円形領域で 近似すると, その半径は距離の 4.5 倍以内である。た だし, これは誘導される範囲の最大值で, 付加導体が 他の導体に囲まれた閉領域の場合には，誘導される範 囲は狭くなる。

（3）提案手法の解析プログラムは, 従来法の解析 プログラムに対して既知解に関する部分の修正のみで 作成することができ，提案手法の適用は容易である。

（4）実用例として電力ケーブル内に球状の微小金 属異物が混入した場合の電界解析を行い，提案手法の 有効性を示した。

(平成 5 年 3 月 29 日受付, 同 5 年 6 月 14 日再受付)

\section{文献}

（1）河野・宅間：数值電界計算法（昭 55）コロナ社

(2) 宅間: 電学誌, 108, 209 (昭 63-3)

(3) 大久保: 同上, 110, 523 (平 2-9)

（4）美咲・坪井・位高・原：電学論 A, 101，499（昭 56-10)

（5）花井・小山・青柳・村瀬・大島：同上 B， 111，1044（平 3-10)

(6) 坪井・美咲: 同上 $A, 103 ， 675$ (昭 58-12)

（7）坪井・美咲: 同上 $\mathrm{A}, 106,307$ (昭 61-7)

（8）坪井・美咲・矢野: 同上 A, 107，201（昭 62-4)

(9) 坪井・石井 : 同上 $A, 109,399$ (平元-9)

（10）プリンツ(增田・河野共訳)：電界計算法 (昭 49）朝倉書店

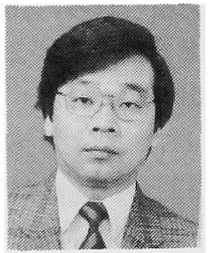

坪 井 始 (正員)

昭和 27 年 4 月 23 日生。 53 年 3 月岡 山大学大学院修士課程修了。同大学工学 部電気工学科助手, 同助教授, 福山大学 工学部情報処理工学科助教授を経て, 平 成 3 年 4 月同教授となり, 現在に至る。工学博士。主とし て, 電磁界の数値解析とその電気・電子機器の最適設計へ の応用に関する研究に従事。

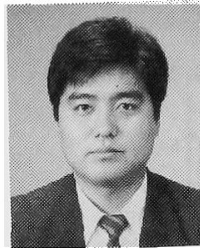

田中始 男 (正員)

昭和 39 年 8 月 11 日生。平成元年 3 月 岡山大学大学院修士課程修了。同年 4 月 福山大学工学部情報処理工学科助手, 5 年 10 月同講師となり, 現在に至る。工 学博士。主として, 境界要素法による電磁界解析に関する 研究に従事。

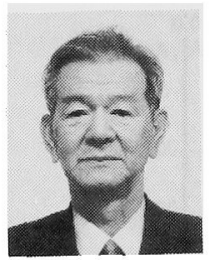

美 咲 隆 吉（正員）

大正 11 年 10 月 2 日生。昭和 21 年 9 月京都大学工学部電気工学科卒業。38 年岡山大学工学部電気工学科教授, 63 年 4 月同大学名誉教授。6 63 年 4 月福山 大学工学部情報処理工学科教授となり, 現在に至る。工学 博士。主として, 電界および電磁界の数值解析に関する研 究に従事。

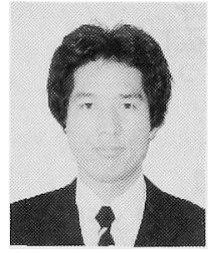

\section{八 束 健 (正員)}

昭和 24 年 9 月 7 日生。 50 年 3 月大阪 工業大学大学院工学研究科電気工学専攻 修士課程修了。同年住友電気工業(株)入 社。現在, 電力システム技術研究所主任 研究員。主として, 電力ケーブルの研究に従事。

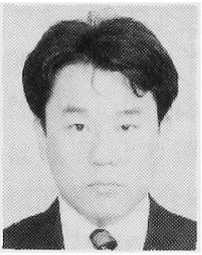

\section{岸幸 治 (正員)}

昭和 40 年 8 月 1 日生。平成 2 年 3 月 東京農工大学大学院工学研究科電気工学 専攻修士課程修了。同年住友電気工業 (株) 入社。現在, 電力システム技術研究 所勤務。主として, 電力ケーブルの研究に従事。 